Identifikasi Paparan Pediculus Humanus Capitis pada Anak Asuh di Panti Asuhan

\title{
Identification of Pediculus Humanus Capitis Exposure in Foster Children at the Orphanage
}

\author{
RIANITA PUTRI \\ FITRIANI KAHAR
}

\author{
Jurusan Analis Kesehatan Poltekkes Kemenkes Semarang \\ Jl. Wolter Monginsidi Pedurungan Tengah Semarang \\ Email:putririanita90@gmail.com
}

\begin{abstract}
Abstrak
Pediculus humanus capitis ialah salah satu parasit yang disebut dengan kutu kepala. Parasit ini menyebabkan gatal-gatal yang mengganggu konsentrasi, serta iritasi di kulit kepala. Salah satu faktor penyebaran parasit ini adalah Personal hygiene yang rendah dan cepat meluas dalam lingkungan tempat tinggal yang padat. Tujuan dari penelitian untuk mengetahui gambaran terhadap paparan Pediculus humanus capitis pada anak asuh di Panti Asuhan An-Nahl Kabupaten Sragen. Metode Penelitian ini ialah penelitian deskriptif melalui pendekatan cross sectional. Hasil penelitian ini menunjukkan 12 Anak asuh (86\%) di salah satu Panti Asuhan ditemukan Pediculus humanus capitis dan 2 Anak asuh (14\%) tidak ditemukan Pediculus humanus capitis. Anak asuh di Panti Asuhan An-Nahl yang memiliki kategori Personal hygiene baik sejumlah 2 anak asuh (14\%) negatif terpapar Pediculus humanus capitis, kategori cukup sejumlah 4 anak asuh (29\%) positif terpapar Pediculus humanus capitis, kategori Personal hygiene buruk sejumlah 8 anak asuh (57\%) positif terpapar Pediculus humanus capitis.Kesimpulan penelitian Pediculus humanus capitis ditemukan pada Anak asuh di Panti Asuhan, sebanyak 57\% dari seluruh Anak asuh memiliki personal hygiene buruk.
\end{abstract}

Kata Kunci : Personal Hygiene ; Pediculus Humanus Capitis ; Panti Asuhan

\begin{abstract}
Pediculus humanus capitis is a parasite known as head lice. This parasite causes itching that interferes with concentration, as well as irritation of the scalp. One of the factors for the spread of this parasite is personal hygiene that is low and quickly spreads in a crowded living environment. The purpose of this study was to describe the exposure to Pediculus humanus capitis in foster children at the Orphanage. This research method is descriptive research through cross sectional approach. The results of this study showed that 12 foster children (86\%) in An-Nahl Orphanage, Sragen Regency had Pediculus humanus capitis and 2 foster children (14\%) did not find Pediculus humanus capitis. Foster children at the Orphanage who have good personal hygiene category, 2 foster children (14\%) are negatively exposed to Pediculus humanus capitis, sufficient category is 4 foster children (29\%) are positively exposed to Pediculus humanus capitis, bad personal hygiene category is 8 foster children (57\%) were positively exposed to Pediculus humanus capitis. The conclusion of the study was Pediculus humanus capitis was found in foster children at Orphanage, as many as 57\% of all foster children had poor personal hygiene.
\end{abstract}

Keywords: Personal Hygiene ; Pediculus Humanus Capitis ; Orphanage 


\section{Pendahuluan}

Salah satu parasit yang banyak ditemukan dalam negara berkembang ialah Pediculus humanus capitis (Djuanda, 2015). Berdasarkan 55 kasus dari berbagai negara di dunia, mayoritas subjek penelitiannya ialah imigran, pelajar, panti asuhan dan tempat kumuh. tampak penelitian yang dilaksankan di negara-negara Asia menemukan pravelansi berkisar dari 0,7 hingga 59\% (Guanther, 2015). Sedangkan menurut Eliska (2015) diperkirakan sekitar 15\% anak Indonesia terinfeksi Pediculus humanus capitis.

Infeksi Pediculus humanus capitis sering dianggap ringan, khususnya negara yang memiliki pengutamaan kesehatan yang lebih serius lainnya. namun, Infeksi Pediculus humanus capitis di seluruh negara mengakibatkan morbiditas yang signifikan. Penyebaran Infeksi Pediculus humanus capitis dapat dipengaruhi dari berbagai faktor termasuk faktor tingkat ilmu pengetahuan, Personal hygiene (kebersihan perorangan), kepadatan hunian, sosial-ekonomi, dan ciri khas individu meliputi tipe rambut, usia, dan juga panjang rambut (Hardiyanti, 2015).

Higiene perorangan berkaitan dengan kebersihan tubuh perseorangan. Manusia adalah sumber pertumbuhan mikroorganisme yang menyebabkan penyakit pada manusia. Usaha higiene perorangan di rumah dapat dilakukan sehari-hari (Kahar, 2019). Personal hygiene yang buruk sebagai faktor penyebab utama yang dapat meningkatkan terjadinya infeksi masuk ke bagian tubuh seperti rambut, kulit kepala ataupun bagian tubuh lainnya. Personal Hygiene yang dijaga dengan baik secara langsung ataupun tidak langsung pada orang yang mengalami Pediculosis capitis merupakan salah satu tindakan preventif terbaik selain mengobati terjadinya penyakit tersebut (Tarwoto \& Wartonah, 2004). Pediculosis capitis cepat meluas dalam lingkungan tempat tinggal yang padat, contohnya di panti asuhan dan asrama. Hal ini disebabkan karena tak jarang dari mereka bertukar makanan dan tempat tidur serta belum adanya perhatian dari berbagai pihak dalam segi kebersihan, perilaku, serta kepedulian terhadap kesehatan (stone et al, 2012).

Anak asuh di panti asuhan masih menerapkan tidur bersama satu kamar ditempati 5-6 orang sehingga dapat dengan mudah menimbulkan infeksi Pediculus humanus capitis melalui penularan secara kontak langsung. Beberapa anak asuh mengeluhkan gatal-gatal di kepala dan ditemukan telur kutu rambut secara visual sehingga diduga bebarapa anak asuh di panti asuhan terinfeksi Pediculus humanus capitis. Menurut hasil wawancara dengan pengasuh belum pernah dilakukan penelitian mengenai Pediculus humanus capitis di Panti asuhan sebelumnya. Adanya kebersihan pribadi yang rendah, maka mudah untuk menimbulkan infeksi Pediculus humanus capitis. Karena mereka tinggal bersama maka penularan kontak langsung bisa terjadi.

\section{Metode}

Peneliti menggunakan jenis penelitian deskriptif dengan pendekatan cross-sectional. Besar sampel ditentukan dengan teknik total sampling, dimana jumlah sampel sama dengan populasi sehingga Sampel dalam penelitian ini adalah semua anak asuh di panti asuhan, yaitu berjumlah 14 orang. Kemudian data hasil pemeriksaan diolah dan ditampilkan secara deskriptif dalam bentuk tabel frekuensi.

\section{Hasil dan Pembahasan}

Dari 14 responden, terdapat 12 responden yang terinfeksi pediculus humanus capitis (86\%), dan 2 responden yang tidak terinfeksi pediculus humanus capitis (14\%). Hasil penelitian menunjukkan bahwa sebanyak $86 \%$ dari seluruh responden terinfeksi Pediculus humanus capitis yang diperoleh dari hasil pemeriksaan rambut dengan metode sisir serit yang 
terlihat pada Gambar 1 dan 2 yang menunjukkan telur kutu rambut secara visual yang menempel pada rambut anak asuh.

Gambar 1. Hasil penyeritan rambut pada anak asuh ditemukan kutu rambut

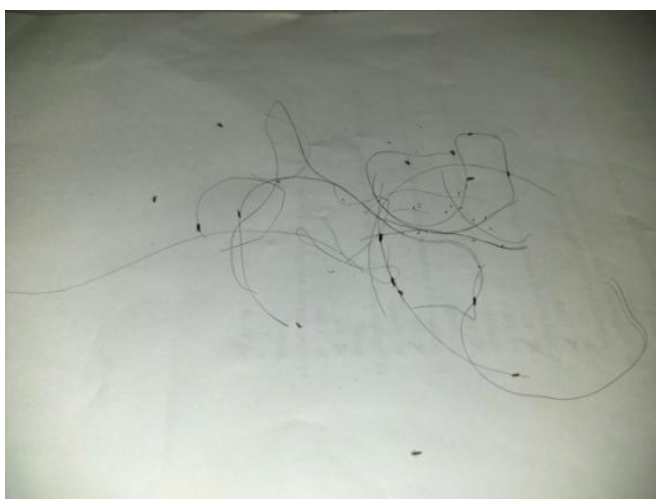

Gambar 2. Terlihat secara visual telur kutu rambut yang menempel pada rambut anak asuh

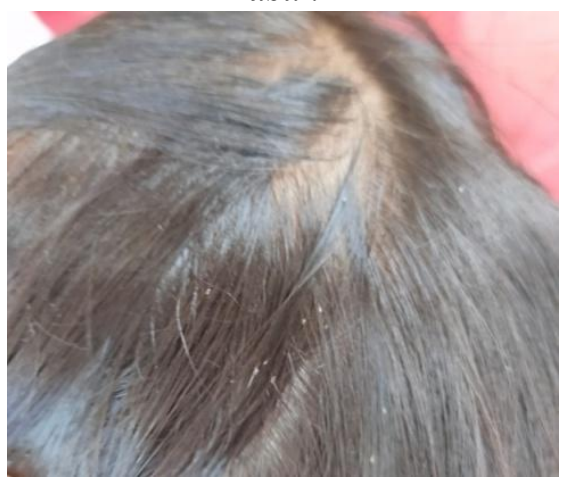

Tabel 1. Distribusi dan frekuensi Pediculus humanus capitis di Panti Asuhan An-Nahl Kabupaten Sragen

\begin{tabular}{ccc}
\hline $\begin{array}{c}\text { Pediculus humanus } \\
\text { capitis }\end{array}$ & Frekuensi (n) & Presentase (\%) \\
\hline Positif & 12 & $86 \%$ \\
Negatif & 2 & $14 \%$ \\
\hline Jumlah & 14 & $100 \%$ \\
\hline
\end{tabular}

Berdasarkan hasil wawancara kebanyakan responden mengalami gatal gatal di area kepala sehingga menggangu konsentrasi saat belajar dikarenakan sering menggaruk garuk kepala. Hal ini sesuai dengan gejala Pediculosis capitis yang disebutkan oleh yousefi et,al (2012) menyebutkan kebiasaan menggaruk kulit kepala secara intensif yang disebabkan adanya Pediculus humanus capitis di kulit kepala dapat menimbulkan iritasi ataupun luka di kulit kepala serta dapat mengganggu konsentrasi, dan memungkinkan terjadinya infeksi sekunder oleh jamur ataupun bakteri sehingga timbul demam pada infestasi berat.

Penyebaran Pediculus humanus capitis dapat terjadi karna perilaku Personal hygiene anak asuh. Pada tabel 2 dapat diketahui bahwa dari 14 responden terdapat 2 responden negatif ditemukan Pediculus humanus capitis dengan Personal hygiene baik (14\%), 4 responden memiliki Personal hygiene cukup positif ditemukan Pediculus humanus capitis 
(29\%), 8 responden memiliki Personal hygiene buruk positif ditemukan Pediculus humanus capitis $(57 \%)$

Tabel 2. Distribusi dan frekuensi Personal hygiene dengan Pediculus humanus capitis

\begin{tabular}{lllll}
\hline \multirow{2}{*}{ Personal hygiene } & \multicolumn{2}{c}{$\begin{array}{c}\text { Pediculus humanus } \\
\text { capitis }\end{array}$} & \multicolumn{2}{c}{ Total } \\
\cline { 2 - 5 } & Positif & Negatif & $\mathrm{N}$ & $\%$ \\
\hline Hygiene baik & 0 & 2 & 2 & $14 \%$ \\
Hygiene cukup & 4 & 0 & 4 & $29 \%$ \\
Hygiene buruk & 8 & 0 & 8 & $57 \%$ \\
\hline Jumlah & 12 & 2 & 14 & $100 \%$ \\
\hline
\end{tabular}

Pada tabel 2 Sebanyak $57 \%$ dari seluruh responden memiliki Personal hygiene buruk, dari 14 responden yang terinfeksi Pediculus humanus capitis sebanyak 12 responden, yang memiliki Personal hygiene buruk sebanyak 8 responden (57\%), 4 anak asuh memiliki Personal hygiene cukup dan 2 responden (14\%) memiliki Personal hygiene baik. Untuk mengetahui personal hygiene anak asuh peneliti menggunakan pengisian kuesioner sebagai alat ukur. Dari hasil pengisian kuesioner Personal hygiene yang masih kurang adalah bertukar pakaian dan sisir. terdapat 12 anak asuh yang bertukar pakaian seperti jilbab dan 8 anak asuh yang bertukar sisir. ini menunjukkan mayoritas responden saling bertukar pakaian dan sisir menyebabkan sebagian anak asuh positif terinfeksi Pediculus humanus capitis Hal ini searah dengan penelitian yang dilaksanakan oleh Restiana (2010) yang terlihat bahwa ada hubungan antara penggunaan sisir secara bergiliran dengan kejadian Pediculosis capitis dengan $p$ value $=0,019$. Menurut pengamatan peneliti terhadap kegiatan sehari-hari santri, sudah menjadi kebiasaan dikalangan santri untuk bertukar barang baik itu kerudung atau pakaian, bahkan.sisir, dan aksesoris rambut seperti kuncir rambut ataupun jepitan rambut yang mendukung transmisi tidak langsung Pediculus humanus var. capitis.

Pengisian kuesioner oleh responden menunjukkan bahwa mayoritas responden yang positif terinfeksi Pedikulosis kapitis mempunyai Personal hygieneyang cukup (29\%) dan 14\% memiliki Personal hygieneyang baik. Hasil penelitian ini menunjukkan bahwa responden dengan Personal hygienecukup yang terinfeksi kutu kepala selalu mencuci rambut menggunakan sampo, mengganti pakaian minimal dua kali sehari, menggunakan handuk sendiri dan menggunakan sisir sendiri. Meskipun Personal hygieneresponden tergolong cukup, namun terdapat beberapa jalur yang menjadi transmisi penularan kutu kepala. Berdasarkan hasil dari jawaban kuesioner, penularan kutu kepala dapat melalui penggunaan pakaian (baju, kerudung) dan tidur bersamaan. Hal ini didukung dengan data bahwa 12 responden (86\%) menggunakan pakaian (baju, kerudung) secara bergantian dengan anak asuh yang lain dan 8 responden (57\%) menggunakan sisir secara bergantian dengan anak asuh lain dan seluruh anak asuh masih tidur bersama. Hal ini didukung dengan penelitian nadira (2019) bahwa responden yang memiliki Personal hygiene cukup memiliki risiko 2,678 kali lebih besar terinfeksi Pedikulosis kapitis yang berarti dapat terinfeksi Pediculus humanus capitis. Dan sesuai dengan yang diungkapkan oleh Frankowski dan Bocchini (2010) bahwa penularan kutu kepala secara tidak langsung dapat melalui kontak dengan barang pribadi individu yang terinfeksi, misal sisir, topi, kerudung, aksesoris kepala, dan peralatan tidur. $\mathrm{Hal}$ inilah yang menyebabkan responden tetap terinfeksi oleh kutu kepala meskipun personal hygiene-nya tergolong cukup. Tingkat kepadatan hunian dapat menjadi salah satu faktor yang berpengaruh terhadap adanya kejadian pediculosis capitis dan adanya ketidaksesuaian jumlah santri dan jumlah huniannya di dalam panti asuhan tersebut. Satu kamar dapat dihuni lebih dari 5-6 orang itu menyebabkan prevalensi penyebaran pediculosis capitis lebih cepat, diperburuk juga lagi dengan Personal hygiene anak asuh yang rendah. 


\section{Simpulan dan Saran}

\section{Simpulan}

Pediculus humanus capitis ditemukan pada anak asuh di Panti Asuhan yang positif terpapar Pediculus humanus capitis sejumlah 12 Anak asuh (86\%) dan yang negatif terpapar Pediculus humanus cspitis sejumlah 2 Anak asuh.

Anak asuh di Panti Asuhan yang memiliki kategori Personal hygienebaik sejumlah 2 anak asuh (14\%) negatif terpapar Pediculus humanus capitis, kategori cukup sejumlah 4 anak asuh (29\%) positif terpapar Pediculus humanus capitis, kategori Personal hygieneburuk sejumlah 8 anak asuh (57\%) positif terpapar Pediculus humanus capitis. Personal hygiene yang masih kurang antara lain kebiasaan tidak mengganti pakaian $2 \mathrm{x}$ sehari, jarang mencuci sprei tempat tidur, penggunaan tempat tidur bersama, kegiatan keramas yang tidak lebih dari $2 \mathrm{x}$ seminggu, dan bertukar barang pribadi seperti pakaian, jilbab.

\section{Saran}

Dengan penelitian ini peneliti diharapkan dapat membagi ilmu/wawasan dan lebih meningkatkan ketrampilan maupun ketelitian khususnya dalam bidang Parasitologi.

Penelitian ini diharapkan dapat digunakan sebagai sumber informasi atau sumber data bagi peneliti berikutnya yang akan melakukan penelitian sejenis sehingga dapat dijadikan acuan dengan menambah jumlah sampel penelitian dan mengganti responden penelitian.

Bagi Masyrakat/Anak asuh dan Pihak Panti Asuhan semoga data peneliti dapat bermanfaat dan berguna dalam memberikan informasi mengenai penularan dan pencegahan terhadap Pediculus humanus capitis sehingga sebaiknya Masyrakat/Anak asuh dan Pihak Panti Asuhan selalu memperhatikan kebersihan diri (Personal Hygiene).

\section{Daftar Pustaka}

Djuanda, A. (2015). Ilmu Penyakit Kulit dan Kelamin. Edisi 7. Jakarta : Badan Penerbit FKUI.

Eliska, N. (2015). Pediculosis Capitis. Availabelat: https://dokumen.tips/documents/pediculosis-kapitis-55f3076e6d4a3.html

Frankowski, B. L., dan J. A. Bocchini. (2010). Clinical report: Head Lice. American Academy of Pediatrics

Guanther, L. C. (2015). Pediculosis and Pthiriasis (lice infestasion). Medscape.

Hardiyanti, Nani Indah., dkk. (2015). Penatalaksanaan Pediculosis Capitis. Lampung: Universitas Lampung.

Kahar, F. (2019). Analisis Hubungan Higiene Perorangan dengan Kejadian Kecacingan Siswa Siswi SDN Barombong Kota Makassar. UNM Environmental Journals, 2(1), 12-17. DOI: https://doi.org/10.26858/uej.v2i1.9159

Nadira, Warda Ayu. (2019). Hubungan antara personal hygiene dan kepadatan hunian dengan kejadian pediculosis capitis di desa sukogidri jember. Jember :digital repository universitas jember.

Rahmawati, A. (2019). Effects of Hygiene Hygiene Against Worm Infection in Elementary Children. Jaringan Laboratorium Medis, 1(1), 6-10.

Restiana, R. (2010). Hubungan Berbagai Faktor Risiko Terhadap Angka Kejadian Pedikulosis kapitis di Asrama. Tesis. Yogyakarta: Fakultas Kedokteran Universitas Muhammadiyah Yogyakarta.

Wartonah, Tarwoto. (2010). Kebutuhan Dasar Manusia dan Proses Keperawatan. Jakarta: Salemba Medika.

Yousefi, S, Shamsipoor F, Abadi YS. (2012). Epidemiologi Study Of Head Luose (Pediculus Humanus Capitis) Infestation Among Primary School Students In Rural Areas Of Sirjan Country, South Or Iran. Thrita J Med Sci. 